\title{
AN ANALYSIS OF WRITTEN ERRORS; A CASE OF SECOND SEMESTER STUDENTS OF ENGLISH
}

\author{
Wardah Hayati \\ Wardahdinda@gmail.com
}

English Department Tarbiyah Faculty

UIN Antasari Banjarmasin

\begin{abstract}
Article History:
Abstract Errors are envitable happen during the process of

Received: $30^{\text {th }}$ May 2019 learning a language. Students of English majoring in UIN A Antasari also frequently make errors in their witten respon during reading comprehension class. By analying written paper

Accepted: $14^{\text {th }}$ June 2019 of these 28 students the researcher aims to know the areas as well as the types ot their errors. The analysis on 114 student

Corresponding written errors shows that the students made errors in the areas of to be/auxiliary, subject-verb agreement, lexical, preposition,

Author: noun clause, possessive, verb, noun phrase construction, pluralization, and article. The most errors was in the area of

Tel.: tobe/ auxiliary with 34 errors while the least one is in article. Types of errors found in this study are misformation, omission,

Keywords addition and misordering. The anlysis indicates that the errors

Errors; are resulted from interlingual errors indicating interference from Bahasa.
\end{abstract}

Error analysis;

Area of errors;

Types of errors

\section{INTRODUCTION}

Making errors in the process of learning language is quite difficult to avoid especially in learning foreign language. Even in learning native language, learners make countless errors. Many experts presented definitions of error which are basically contain the same idea. The researcher here quotes only two definitions of error. In Norrish's opinion error is " a systemic deviation when a learner has 
learnt something and consistently gets it wrong" (1987). In line with this statement, Cunningworth defines errors as systemic deviationfrom the norms of the language being learnt (1987). In these two definitons the word "systemic deviation" can be taken into account as the key word, So it can be interpreted that the unwanted form happens repeatedly.

In language teaching and learning sometimes the word error and mistake used interchangably. Lexically error and mistake are different. Norrish (1983) says that a mistake is an inconsistent deviation that is sometimes the learner gets it right but sometimes wrong. Richard defines error in speech or writing as the use of linguistic items such as word, gramatical items, speech acts etc in a away which a fluent or native speaker of the languange regards as faulty or incomplete learning (1985). So, students make errors because of lack of knowledge of the target language. On the other hand, according to Richard learners make mistake when writing or speaking due to lack of attention, fatigue, carelesness or other aspects of performance. It can be concluded that a mistake that is made by a learner because he/she does not apply the rules that he has already learnt and a mistake is non systematic.

Dullay, Burt \& Krashen in James (2013) classifies language learning error into 4 principal ways and then James adds the fifth category. They are; 1) ommission, 2) addition, 3) misformation, 4) misordering and blends. This reasearch follows this category.

There are many causes which lead to error in learning a second or foreign language. Norrish (1983) categorizes three types of error causes. The first is carelessness, This is often closely related to lack of motivation. The second cause is interference from the first language. As Norris says that learning a language is actually a matter of habit formation. When somebody learns a new language means the new habits, then the old habits will interfere the new ones. The last cause is because of translation. Students usually translate his first language words, phrases, sentences and idiomatic expression into the target language. Meanwhile, Richards (1971) classify causes of error into four. They are; 1) over generalization, 2) incomplete application of the rules, 3) false concepts hypothesis, and 4) ignorance of rule restriction. According to Brown (1994), 
learners' errors do not happen just because of interference but also because of second language system. That is the causes of errors could be interlingual and intralingual transfer. Further, he states that the sources of first language interference might be because of a number of interferences such as grammatical, prepositional, and lexical interference.

In relation to the learner's errors, there are two different prespectives. The Behaviourist believes that in order to achieve a perfect language teaching, the occurance of learner's errors should be avoided. On the other hand, Cognitivist views that inspite of all the teacher's efforts, still errors are unavoidable, In relation to second language acquisition precess, Corder in James (2013) claimed that errors are useful for both teacher and learners as well as the researcher. Errors inform the teacher what needs to be taught and teaching styles. For learners errors are means for them to test their hypothesis about the target language and then by getting feedback learners can improve their proficiency. While for the reasearcher, errors could tell about how learning proceed.

In light with this, the issue of error analysis was considered as a way to overcome the difficulties in second or foreign language learning, Brown (1994) defines error analysis as " the process to observe, analyze, and classify the deviations of the rules of the second languages and then to reveal the system operated by the learners". Like Brown, Crystal (1999) also states that error analysis in language teaching and learning is the study of the unacceptable forms produced by the language learner, especially a foreign language learner. Richards et.al (1985) state that error analysisi is the study of errors made by the second and foreign learners. Further the result of error analysis could be benefit as information on how well learner knows a language, how a learner learns a language, and learner's difficulties in language learning. So error analysis treats learner errors as a feedback opportunity either for learner, teacher or even for the researcher to determine learning strategies. By conducting error analysis the learners' problem can be described well and then language teachers can be informed about how to overcome the errors.

In UIN Antasari Banjarmasin, students of English majoring who are in their second semester have already some basic knowledge of English. They have 
started learning learning English in senior high school and then have passed basic English program in the Center of Language Learning. In English majoring have already learnt basic grammar, reading, vocabulary, speaking and writing. During this semester the researcher teaches reading II and during the process of teaching and learning, in order to check the students comprehension the researcher usually asks them to answer the reading comprehension questions whether orally or writtenly. Or quite often the researcher asks the students to respond a text according to their own experience as follow up activities. However, the researcher frequently finds errors in their written answers. These experiences encourage the researcher to conduct an error analysis on their written works. Though there are a good number of research have been conducted on this subject but I believe there would be different result and solution in every different case study of error analysis. This reasearch aims to find out the areas and types of gramatical errors that English majoring students make in their written works.

\section{METHOD}

This study is a case study, the case consisting of specific learners of second semester students of English majoring in English Department of UIN Antasari Banjarmasin. There are 28 students, male and female, The data are collected from the students' written answers of midtest and final test on the subject of Reading II.

The researcher employed the procedural analysis of Corder (1974) for this study. The procedure has the following steps : 1. Collection of sample of learner errors through their written answers, 2. Identification of errors and 3. Description of Errors.

\section{FINDINGS AND DISCUSSIONS}

\section{Findings}

After analyzing the students' written answers on types of errors they make, there were 119 errors which can be included into (ten) categories. The errors are in the areas of to be/auxiliary (34), subject-verb agreement (17), lexical (16), preposition (10), noun clause (10), possessive form (7), verb (6), noun phrase construction (5), pluralization (5), and article (4). So, the most errors made by the 
second semester students of English was in the area of tobe/ auxiliary with 34 errors while the least one is in article.

Table 1. The Frequency of Error Types

\begin{tabular}{|c|c|c|c|}
\hline No & Types of Error & Number of Errors & Percentage \\
\hline 1 & $\begin{array}{l}\text { To be/ Auxiliary } \\
-\quad \text { Omission } \\
-\quad \text { Addition } \\
-\quad \text { Misformation }\end{array}$ & $\begin{array}{l}16 \\
12 \\
6\end{array}$ & $29.82 \%$ \\
\hline 2 & $\begin{array}{l}\text { Subject-Verb Agreement } \\
-\quad \text { Omission } \\
-\quad \text { Addition } \\
-\quad \text { Misformation }\end{array}$ & $\begin{array}{l}8 \\
2 \\
7\end{array}$ & $14.91 \%$ \\
\hline 3 & $\begin{array}{l}\text { Lexical item } \\
-\quad \text { Misformation }\end{array}$ & 16 & $14.03 \%$ \\
\hline 4. & $\begin{array}{l}\text { Preposition } \\
\text { - } \text { Omission } \\
\text { - } \text { Addition } \\
\text { - } \text { Misformation }\end{array}$ & $\begin{array}{l}2 \\
1 \\
7\end{array}$ & $8.77 \%$ \\
\hline 5. & $\begin{array}{l}\text { Noun Clause } \\
-\quad \text { Misordering }\end{array}$ & 10 & $8.77 \%$ \\
\hline 6. & $\begin{array}{l}\text { Possessive } \\
\text { - Misformation }\end{array}$ & 7 & $6.14 \%$ \\
\hline 7. & $\begin{aligned} \text { Verb } & \\
- & \text { Omission } \\
- & \text { Addition } \\
- & \text { Misformation }\end{aligned}$ & $\begin{array}{l}4 \\
1 \\
1\end{array}$ & $5.26 \%$ \\
\hline 8. & $\begin{array}{c}\text { Noun Phrase construction } \\
\text { - Misordering }\end{array}$ & 5 & $4.38 \%$ \\
\hline
\end{tabular}




\begin{tabular}{|c|c|c|c|}
\hline 9. & $\begin{array}{l}\text { Pluralization } \\
\begin{array}{l}\text { - } \text { Omission } \\
-\quad \text { Misformation }\end{array}\end{array}$ & $\begin{array}{l}3 \\
2\end{array}$ & $4.38 \%$ \\
\hline 10. & $\begin{array}{l}\text { Article } \\
-\quad \text { Omission }\end{array}$ & $\begin{array}{l}4 \\
4\end{array}$ & $3.51 \%$ \\
\hline & Total number of Errors & 114 & $99.97 \%$ \\
\hline
\end{tabular}

Table 1 also displays categories of error types in the students' works. They are omission, addition, misformation, and misordering. As seen in the table, misformation forms the majority of the types errors amounting to half $(40.35 \%)$ among the other types and this is closely followed by the omission type (31.57\%). Addition (14.03\%) and misordering (13.15\%) are approximately close to each other.

\section{Discussions}

In this part the researcher wants to discuss about the finding and give examples of each gramatical error.

1. The errors on to be/ auxiliary have been noted in the students written works.

To be in English complementif construction does not have lexical meaning but it has gramatical meaning. In Bahasa Indonesia (later shortened as Bahasa) there is no to be/ auxiliary and then students transfer this rule into English, so this kind of errors is the most frequently found in students' works particularly in this research. From 34 errors in to be/auxiliary, 15 erros are about omission of be, For examples :

$\underline{\text { He so }}$ sad (He was so sad)

You from rich family. (You are from rich family)

I also a vegetarian. (I am also a vegetarian)

The rest parts for errors happen due to over generalization by adding unnecessary to be in verbal sentences and misformation sentences choosing uncorrect form of to be. For examples

$\underline{\text { I am eat fast food }}$ (I eat fast food) 
They are have a good life (They have a good life)

There is so many people (There are so many people)

2. The errors in S- V agreement is also due to interference from Bahasa. In Bahasa, there is no changes in the verb whether the subject is singular or plural. For example:

Dia pergi ke pasar

Mereka pergi ke pasar

The verb "pergi" in both sentences does not change eventhough the subjects are different, If the students apply this rule into English, they will make sentences such as

$\underline{\mathrm{He} / \mathrm{she} \text { go }}$ to market

They go to market

In this research the case of omisson of verb maker for the third person in present tense (s/es) happened for 8 cases. The students simplified the rule of the target language. For examples

$\underline{\text { Mc Donald give a good influence (Mc Donald gives good influence) }}$

Because it make me allergetic (Because it makes me allergetic)

He tell how to live in America (He tells how to live in America)

The other cases of erros happened because of overgeneralization or confuse with plural signal so the students added "s" to the verb of plural subject and misselection of unsuitable concord, The examples are

They treats them less than human (They treat them less than human)

The countries was destroyed

(The countries were destroyed)

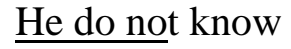

(He does not know)

3. The third common errors are about lexical misformation. The source of this area of errors resulted from students' limited vocabulary, They were confused and then used translation in diffrentiating adjective vs noun, verb vs adjective and verb vs noun, etc. For examples;

It will impact our healthy

(It will impact our health)

That job was very enjoy

(That job was very enjoyable)

You can have a good live

(You can have a good life)

Respect others and work hardly

(Respect others and work hard) 
4. Errors in preposition happened in types of omission, misformation and addition. The source of errors in this area is because the students mostly employed translation to find out preposistion that they want to use. Since a word in Bahasa may have similar meaning in English and vice verse, they used uncorrect prepositions, In Bahasa, “ untuk" can be translated into "to or for" and "dengan" can be translated into "with or by". So the students made the folowing errors:

With work hard...

We work hard for get achievement
(By working hard)

(We work hard to get achievement)

\section{We left from Minnesota (We left Minnesota)}

5. There are 10 errors in the area of noun clause and all of the errors are in types of misformation that is false in word ordering. The students ignore of the rule that not to use question word order in a noun clouse. In a noun clause, the subject proceeds the verb. Does, do and did are used in questions but not in noun clause (Azar, 1989). The examples that the students made in this area are:

They want to know where do you come from.

They want to know where you come from

It does not really a matter where are we from.

It does not really a matter where we are from.

6. All of errors in possessive case are due to misselection of the correct forms to used. The students were still confused about the possessive pronoun, possessive adjective, subjective form and possessive adjective, and even with objective form. For examples
...Because its delicious
(,,,because it is delicious)
The invaders killed they family
(The inveaders killed their family)
The Americans take they life.
(The Americans take their life)

7. Omission, addition and misformation are error types that happened in verb. Errors in this area are mostly due to uncomplete application of the rule in target language so for example the students correct in applying to be and verb for making passive voice but forgot that the verb should be in past 
participle form. Or in other occasio they miss to infinitive or redundent by having -ing form after to infinitive verb. For examples:

They were welcome

I eat to hanging out with friends.

...if they want keep alive
They were welcomed

I eat to hang out with friends

...if they want to keep alive.

8. Noun phrase constuction is the next area of errors. All the errors in this cases is due to misformation, Noun phrase construction in Bahasa has an opposite rule compared with English, the adjective modifier should be put in after the head (noun). The students as because of direct translation applied this rule, so they made errors such as:

I do not want to eat food unhealthy I do not want to eat unhealthy food. You must be a worker hard. $\quad$ You must be a hard worker

9. Three cases of omission and 2 cases of misformation arose in area of pluralization. In Bahasa, plural quantifier does not affect the noun. For example:

Saya punya lima buah rumah or

I have five house

That is why when the students applied this rule in English, they made the kind of errors. They considered redundant to have double plural markers. Other source of errors in this case because of msformation of the irregular construction of plural.

It caaused many war

The bad thing is that other reastaurant.

The Americans took their life
It caused many wars

The bad thing is that other restaurants

The Americans took their lives

10. The last category is errors in article. All the errors in article happened because the students omit the articles. The students have difficulty in using and differentiating definite, indefinite articles. In Bahasa it is permitable not to mention about article, For example: Ani (adalah seorang) gadis yang cantik. It is acceptable to say "Ani gadis yang cantik". Examples of errors in articles are:

Mc Donald is very successful restaurant. 
Mc Donald is a very successful restaurant

Life is like wheel

Life is like a wheel.

From all the data, it can be seen that some students seem to think in Bahasa style, most of them still translating literary from Bahasa. When the students in this research do not know the appropriate word, or structure, they refer to their Bahasa. This is what Selinker says as "interlanguage" or a half way between their own language and the target language (1972). Next, they also overgeneralize target language rules. They may produce correct form after learning a certain target language structure but when a lot of new language rules come, the learner become confuse and making generalizations. However with the help of feed back of the teacher the students would be able to correct their errors.

\section{CONCLUSIONS AND SUGGESTIONS}

Having analyzed all the data ot this research the writer could draw conclusions that from the 114 written errors produced by the second semester students of English majoring in UIN Antasari, errors exist in the areas of to be/auxiliary, subject-verb agreement, lexical, preposition, noun clause, possessive form, verb, noun phrase construction, pluralization, and article. The most errors made were in the areas of tobe/ auxiliary with 34 errors while the least one is in article with 4 errors. Misformation errors formed an important part of the error data. The other types of errors are ommision, addition and misordering. It is suggested that student errors should not be considered as learning failure. Errors are indispensable from the learners, however in turn they can get benefits from various forms of feedback on these errors. Therefore teachers are expected to provide corrective feedback for their students.

\section{REFERENCES}

Azar, B.S. (1989). Understanding and Using English Grammar, New Jersey: Prentice-Hall, Inc.

Brown, H. D. (1994). Principles of Language Teaching and Learning. New Jersey: Prentice-Hall Inc. 
Cunningworth, A. (1987). Evaluation and Selecting EFL Teaching Materials. London: Heinemann Education Book.

Crystal, D. (1999). The Penguin Dictionary of language (2nd ed). Penguin

Ellis, R. (1994). The Study of Second Language Acquisition. Oxford: University Press.

James, C. (2013). Errors in Language Learning and Use. Exploring Error Analysis. London and NewYork: Routledge Taylor \& Francis Group

Hasyim, S. (2002). Error Analysis in the Teaching of English, Petra e-journal Volume 4, number 1, June 2002: 42-50.

http://puslit.petra.ac.id/journals/letters

Latief, M. A. (2014). Research Methods om Language Learning: An Introduction. Malang: UM Press.

Norrish, J. (1987). Language Learning and Their Errors. London: Macmillan Publisher.

Richards, J.C. (1984). A Non-contrastive Approach to Error Analysis. English Language Teaching 25. London: Oxford University Press.

Selinker, L. (1972). Interlanguage. International Review of Applied Linguistics, 10 , 